\title{
Influence of Geographic Region on Fatty Acid and Physical Properties of Indonesian Cocoa Butter from Smallholder Estate
}

\author{
Hendy Firmanto ${ }^{1 *}$, Supriyanto ${ }^{2)}$, Sri Anggraheni ${ }^{2)}$, Agung Wahyu Susilo ${ }^{1)}$, and Bayu Setyawan ${ }^{1)}$ \\ ${ }^{1)}$ Indonesian Coffee and Cocoa Research Institute, Jl. PB Sudirman 90 Jember 68118 \\ ${ }^{2)}$ Faculty of Agricultural Technology, Universitas Gadjah Mada, Bulaksumur, Yogyakarta 55281 \\ ${ }^{*}$ Corresponding author: hendy.firmant@gmail.com \\ Received: 4 February 2019/ Accepted: 15 March 2019
}

\begin{abstract}
Cocoa butter is the most essensial component in chocolate formulation and represent the biggest characteristic of this product. Indonesia is the third cocoa producers with cocoa producing area spread out in different geographic region and may affect in cocoa butter profiles. The aim of this experiment was to evaluate the fatty acid characteristic and physical properties of cocoa butter from smallholder estate relate to geographic region and climate. This experiment was conducted using unfermented cocoa bean from smallholder estate in eight provinces of Indonesian most growing areas. Fatty acid composition evaluated through the different region and physical properties evaluated in melting profiles and solid fat content. The result explain the fatty acid characteristic of Indonesian cocoa butter consist of palmitic acid (C16:0) 26.28-29.20\%, stearic acid (C18:0) 32,14-37.29\% and oleic acid (C18:1) 32,14-37,29\%. Growing temperature significantly affects the increase of palmitic acid composition contribute to cocoa butter hardness. Cocoa butter completely melt in temperature of $36.65-39.20^{\circ} \mathrm{C}$ and solid fat content ranged $7.288-16.82 \%$ in $33^{\circ} \mathrm{C}$ and ranged $0.02-0.29 \%$ in $38^{\circ} \mathrm{C}$. This Indonesian cocoa butter comply to the classification of hard cocoa butter.
\end{abstract}

Keywords: Cocoa butter, chemical composition, geographic region, physical properties

\section{INTRODUCTION}

Cocoa (Theobroma cacao L.) is grown comercially between $20^{\circ}$ north and south of the Equator with three main-growing areas are West Africa, South East Asia and South America (Beckett, 2009). Indonesia has become the fifth cocoa producer in 2018 after Côte d'Ivoire, Ghana, Ecuador, and Nigria ( ICCO, 2018). Cocoa production areas in Indonesia are occupied by smallholder estate over $60 \%$, widely spread in different geographic region and cilmate condition (McMahon et al., 2015). Butter content of Indonesian cocoa bean reach 49.85-53.67\% higher than bean of both Hainan and Papua
New Guinea (Gu et al., 2013). The chemical quality of cocoa butter largely influence the physical quality characteristic of chocolate such such as hardness at room temperature, brightness, fast and melting behaviour (Saldaña et al., 2002; Afoakwa et al., 2014).

The distinctive properties of cocoa butter as the result of specific AGs structure are non comparable with any other natural edible fat (Zyzelewicz, 2014). Triacylglycerols (TAGs) are the major component present in cocoa butter, making up 92 to $96 \%$ of the lipid composition followed by monoacylglycerols (MAGs) and diacylglycerols (DAGs) (Jahurul et al., 2013). TAGs composition of CB consist 
of 1,3-dipalmitoyl-2-oleoyl-glycerol (POP), 1(3)-palmitoyl-3(1)-stearoyl-2monoolein (POS), and 1,3-distearoyl-2-oleoylglycerol (SOS) with oleic acid in the sn-2 position (Liu at al., 2007). The main fatty acids (FA) of CB are stearic acid (C18:0) 33.7-40.2\%, oleic acid (C18:1) 26.3-35\% , palmitic acid (C16) 25-33.7\%, and linoleic acid (C18:2) 1.7-3\% (Asep et al., 2008). Cocoa butter from Indonesia contains high oleic acid (33.06\% wt) resemble to Ghana (32.99\% wt) and Ivory Coast (32.84\% wt) (Spangenberg $\&$ Dionisi, 2001).

The basis characteristic of cocoa butter and its fatty acid composition may affected by farming region's climate which relate to changes of its saturated and unsaturated chains following temperature and drought factor (Lehrian \& Keeney, 1980; Vieira et al., 2015). Demonstrably, ambient temperature and stress caused by drought affect fatty acid biosynthesis through specific enzymes inside the plant cells (Ohlrogge, 1994). Hightemperature tolerant plant has strongly shown on decreasing its polyunsaturated fatty acid and high tolerant plant in drought express the ability to maintain or adjust fatty acid unsaturation (Upchurch, 2008). Fatty acid saturation is necessary to evaluate according to certain cocoa butter blend formulation and significantly altering the physical properties as crystallization or melting point profiles. These formulation could be essential for the production of high temperature resistant hard butter products for countries with a hot climate (Jahurul et al., 2014).

Indonesian most cocoa growing estate located in Sulawesi island alongside to the equator with average rainfall is $100-1.300 \mathrm{~mm}$ per year (McMahon et al., 2015). Brazilian cocoa estates located in between $5^{\circ} \mathrm{N}$ and $24^{\circ} \mathrm{S}$ with the highest rainfall $2.250 \mathrm{~mm}$ per year while Ghana rainfall value ranged 1000 $\mathrm{mm}$ to $1900 \mathrm{~mm}$ in the forest zone (Amissah et al., 2014; Vieira et al., 2015). Therefore,
Indonesia as potentially the hottest cocoa growing area is necessary to characterize its cocoa butter altogether in different geographic region to determine both physical and chemical composition and to obtain brief comparison with cocoa butter from another countries. The aim of this work was to make a comparative study of the physicochemical properties of raw cocoa butter from different geographical areas in Indonesia as well as assess whether the climate condition produces differences in the physicochemical properties of cocoa butter among the growing areas.

\section{MATERIALS AND METHOD}

\section{Cocoa Sample and Preparation}

Cocoa bean cultivated from eight provinces include West Sumatera, Lampung, East Java, West Sulawesi, Central Sulawesi, South Sulawesi, Southeast Sulawesi, and West Papua. Every provinces require fiveteen estates as composite sample of provinces and involve intensive, semi-intensive and non intensive smallholder estates. The non-fermented cocoa bean were processed (harvesting, pod opening, drying until moisture content 20-25\% and packaging) at the estate, continuing drying before the fitfth days using oven (Ehret, Germany) in temperature $35^{\circ} \mathrm{C}$ until $7-7.5 \%$ held in Indonesian Coffee and Cocoa Research Institute (ICCRI) on Jember, East Java. Table 1 provides information about the cocoa origin taken by Digital Logger Tiny Tag 2.0 and BMKG. The sampling of cocoa beans aimed to cover all the main Brazilian producer states and elaborate actual geographical variations.

Raw cocoa bean (dry and unfermented) determined for weight per bean, bean count and shell content then broke to separated between cotyledon and shell using deshelling machine uquipped with cyclone winnower as describe in Firmanto et al., (2015) and grinded into coarse cocoa mass using mechanical 
Influence of gegraphic region on fatty acid and physical properties of Indonesian cocoa butter from smallholder estate

Table 1. Indonesian geographic region of cocoa cultivation and climate condition of the samples

\begin{tabular}{lclccc}
\hline Samples & Harvesting & \multicolumn{1}{c}{ District/estates } & $\begin{array}{c}\text { Rainfall } \\
(\mathrm{mm} / \text { year })\end{array}$ & $\begin{array}{c}\text { T } \\
\left({ }^{\circ} \mathrm{C}\right)\end{array}$ & $\begin{array}{c}\text { Humidity } \\
(\%)\end{array}$ \\
\hline West Sumatera & Oct/2016 & West Pasaman, Padang Pariaman & 4,249 & 26.33 & 88.50 \\
Lampung & Oct/2016 & Pringsewu, East Lampung, Pasewaran & 1,891 & 26.71 & 70.31 \\
East Java & Oct/2016 & Pacitan, Madiun, Blitar & 1,619 & 25.66 & 88.92 \\
West Sulawesi & Oct/2016 & Majene, Polewali Mandar, Mamuju & 2,103 & 28.57 & 82.07 \\
Central Sulawesi & Oct/2016 & Sigi, Donggala, Parigi Mountong & 2,084 & 27.03 & 82.62 \\
South Sulawesi & Oct/2016 & Soppeng, Pinrang, Luwu & 1,831 & 29.02 & - \\
Southeast Sulawesi & Jan/2017 & Konawe, Kolaka, North Kolaka & 1,679 & 27.48 & 84.78 \\
West Papua & Nov/2016 & Manokwari, South Manokwari & 2,200 & 28.13 & 83.88 \\
\hline
\end{tabular}

grinder as describe in Mulato et al., (2004) to gain particle size of 300-400 $\mu \mathrm{m}$. Cocoa oil extracted from cocoa mass using laboratory hydraulic press unit as describe in Venter et al, (2007). Raw cocoa oil take in isolated water bath (Memmert, Germany) for precipitation for 12 hours on temperature $35^{\circ} \mathrm{C}$. Cocoa oil taken from the upper layer for $75 \mathrm{~mL}$ and molded into block to storage in cooling temperature of $15^{\circ} \mathrm{C}$ into cocoa butter.

\section{Fatty Acid Analysis}

FA profiles were analyzed using a CGC Agilent 6850 capillary gas chromatograph (Santa Clara, CA, USA) after esterification according to the methodology described by Hartman \& Lago (1973). FA methyl esters were separated according to the AOCS Ce1f-96 method (2009). Chromatograph operation conditions: a DB23 Agilent capillary column (50\% cyanopropyl methylpolysiloxane), dimensions $60 \mathrm{~m}$, øint: $0.25 \mathrm{~mm}, 0.25 \mu \mathrm{m}$ film thickness. Analysis conditions: oven temperature program: $110^{\circ} \mathrm{C} / 5 \mathrm{~min}, 110-215^{\circ} \mathrm{C}\left(5^{\circ} \mathrm{C} / \mathrm{min}\right)$, $215^{\circ} \mathrm{C} / 24 \mathrm{~min}$; detector temperature: $280^{\circ} \mathrm{C}$; injector temperature: $250^{\circ} \mathrm{C}$; carrier gas: helium; split ratio 1:50; injected volume: $1.0 \mu \mathrm{L}$. The qualitative composition was determined by comparison of the peak retention times with those of respective FA standards. Quantitative analysis was carried out by normalization of peak areas, expressed as mass percentage.

SFC was determined using nuclear magnetic resonance (NMR) spectrometry
(Bruker MINISPEC PC-120, Rheinstetten, Germany) and Duratech TCON 2000 highprecision dry bath (Carmel, IN, USA) according to the AOCS Cd16b-93 direct method (2009). Sample tempering followed the temperature/time program: $100^{\circ} \mathrm{C} / 15 \mathrm{~min}$, $60^{\circ} \mathrm{C} / 5 \mathrm{~min}, 0^{\circ} \mathrm{C} / 90 \mathrm{~min}, 26^{\circ} \mathrm{C} / 40 \mathrm{~h}$ and finally $0^{\circ} \mathrm{C} / 90 \mathrm{~min}$, after which the samples were kept at each reading temperature (10, $15,20,25,30,35$, and $40^{\circ} \mathrm{C}$ ) for a period of $1 \mathrm{~h}$ prior to registering the measurement. Analyses were performed in triplicate for each sample.

The thermal behavior of $\mathrm{CB}$ was analyzed using TA Instruments Q1000 DSC (New Castle, DE, USA) according to the AOCS Cj1-94 method (2009) with some modifications. The equipment was calibrated with TA Instruments indium (New Castle, DE, USA), Sigma-Aldrich azobenzene and Acros Organics undecane before analysis, and nitrogen was used to purge the system. Then 5-11 mg of melting CB was filled and hermetically sealed in aluminum pans, and an empty pan was used as a reference. The following temperature-time procedure for non-isothermal crystallization was used: equilibration at $80^{\circ} \mathrm{C} / 10 \mathrm{~min}$ and the ramp cooled at $10^{\circ} \mathrm{C} / \mathrm{min}$ to $-40^{\circ} \mathrm{C}$ and maintained for $10 \mathrm{~min}$ to be heated again until $80^{\circ} \mathrm{C}$ at a rate of $5^{\circ} \mathrm{C} / \mathrm{min}$. Each assay was performed in triplicate. Initial temperature (Tonset), peak melting temperature (Tpeak), all in degrees Celsius, and melting enthalpy ( $\ddot{\mathrm{A}} \mathrm{H})$ in $\mathrm{J} / \mathrm{g}$ were determined. 
IBM SPSS Statistics 22 software (Statistical Analysis System) for the statistical treatment of the collected data was used. The differences between means were determined at a $5 \%$ level of significance $(p<0.05)$ using Duncan's test

\section{RESULTS AND DISCUSSION}

\section{Bean Count and Weight}

The characteristic of Indonesian dry bean from smallholder estate in most growing area as shown in Table 2 have range bean count 91-107 beans per $100 \mathrm{~g}$ weight, net weight $1.09-1.43 \mathrm{~g}$ per bean and shell content 12.89 $15.78 \%$. Bean count and shell content have similar value among the provinces resemble to the result of McMahon (2015) held in top production area of Sulawesi, stated the bean count of $60-100$ beans per 100 grams weight, net weight $0.78-1.69$ grams per bean and shell content $11.94-20.25 \%$. This result indicate no significant difference or geographic region factor influence the bean count and shell content. Southeast Sulawesi have low weight and East Java determined as the highest with net weight $1.43 \mathrm{~g} / \mathrm{beans}$, but in other provinces show uniformity, therefore the bean characteristic from smallholder estate among the provinces in Indonesia not differentiate by geographic region or different climate condition in Table 1.

\section{Saturated Fatty Acid Profiles}

Table 3 show saturated fatty acid of cocoa butter from 8 provinces involving 22 district. Saturated fatty acid show significant difference in component of palmitic acid (C16:0), stearic acid (C18:0) and arachidic acid (C20:0). The wet growing area (Table 1) such East Java (temperature $25.66^{\circ} \mathrm{C}$; rainfall $226.60 \mathrm{~mm} /$ year) and West Sulawesi (temperature $28.57^{\circ} \mathrm{C}$; rainfall $214.83 \mathrm{~mm} /$ year) produce more palmitic acid (C16:0) but low stearic acid (C18:0) contrast to low rainfall growing area such Lampung (temperature $26.71^{\circ} \mathrm{C}$; rainfall $197.64 \mathrm{~mm} /$ year) and West Papua (temperature $28.13^{\circ} \mathrm{C}$; rainfall $195.03 \mathrm{~mm} /$ year). Palmitic acid (C16:0) and stearic acid (C18:0) as the

Table 2. Bean count, net weight and shell content of dry bean (non-fermented)

\begin{tabular}{|c|c|c|c|}
\hline Samples & Bean count (beans) & Net weight, $\mathrm{g}$ & Shell content, $\%$ \\
\hline West Sumatera & $99 \pm 5^{a}$ & $1.30 \pm 0.19^{\mathrm{ab}}$ & $13.67 \pm 0.47^{\mathrm{a}}$ \\
\hline Lampung & $101 \pm 1^{a}$ & $1.21 \pm 0.08^{a b}$ & $13.78 \pm 2.69^{\mathrm{a}}$ \\
\hline East Java & $91 \pm 10^{a}$ & $1.43 \pm 0.25^{\mathrm{a}}$ & $13.78 \pm 2.04^{\mathrm{a}}$ \\
\hline West Sulawesi & $96 \pm 3^{a}$ & $1.19 \pm 0.02^{a b}$ & $15.78 \pm 2.14^{\mathrm{a}}$ \\
\hline Central Sulawesi & $107 \pm 5^{a}$ & $1.14 \pm 0.02^{a b}$ & $12.89 \pm 1.39^{\mathrm{a}}$ \\
\hline South Sulawesi & $91 \pm 8^{a}$ & $1.23 \pm 0.21^{\mathrm{ab}}$ & $16.00 \pm 1.76^{\mathrm{a}}$ \\
\hline Southeast Sulawesi & $107 \pm 1^{a}$ & $1.09 \pm 0.13^{\mathrm{b}}$ & $15.78 \pm 1.54^{\text {a }}$ \\
\hline West Papua & $91 \pm 1^{\mathrm{a}}$ & $1.20 \pm 0.00^{\mathrm{ab}}$ & $13.67 \pm 0.47^{a}$ \\
\hline
\end{tabular}

Table 3. Saturated fatty acid composition

\begin{tabular}{|c|c|c|c|c|c|c|c|}
\hline \multirow{2}{*}{ Samples } & \multicolumn{5}{|c|}{ Saturated fatty acid $(\%)$} & \multirow[b]{2}{*}{$\mathrm{C} 20: 0$} & \multirow{2}{*}{ ÓSFA (\%) } \\
\hline & C10:0 & $\mathrm{C} 12: 0$ & $\mathrm{C} 14: 0$ & $\mathrm{C} 16: 0$ & C18:0 & & \\
\hline West Sumatera & $0.02 \pm 0.03^{\mathrm{a}}$ & $0.18 \pm 0.25^{\mathrm{a}}$ & $0.63 \pm 0.73^{\mathrm{a}}$ & $27.28 \pm 0.64$ & ab $35.15 \pm 0.45^{a b}$ & $2.16 \pm 0.78^{a}$ & $65.42 \pm 0.70^{\mathrm{a}}$ \\
\hline Lampung & $\mathrm{ND}$ & $0.10 \pm 0.13^{\mathrm{a}}$ & $0.45 \pm 0.16^{\mathrm{a}}$ & $26.28 \pm 0.11$ & b $36.42 \pm 0.66^{\mathrm{a}}$ & $1.52 \pm 0.13^{\mathrm{ab}}$ & $64.78 \pm 0.69^{a}$ \\
\hline East Java & $0.02 \pm 0.03^{\mathrm{a}}$ & $0.09 \pm 0.11^{\mathrm{a}}$ & $0.23 \pm 0.23^{a}$ & $27.03 \pm 0.21$ & ab $34.59 \pm 0.65^{\mathrm{ab}}$ & $1.63 \pm 0.17^{\mathrm{ab}}$ & $63.58 \pm 2.00^{\mathrm{a}}$ \\
\hline West Sulawesi & $0.01 \pm 0.01^{\mathrm{a}}$ & $0.10 \pm 0.08^{\mathrm{a}}$ & $0.32 \pm 0.26^{\mathrm{a}}$ & $27.75 \pm 0.47$ & ${ }^{a b} 34.61 \pm 0.63^{a b}$ & $1.69 \pm 0.05^{\mathrm{ab}}$ & $64.48 \pm 0.76^{\mathrm{a}}$ \\
\hline Central Sulawesi & $0.04 \pm 0.05^{\mathrm{a}}$ & $0.04 \pm 0.04^{\mathrm{a}}$ & $0.32 \pm 0.31^{\mathrm{a}}$ & $27.44 \pm 0.28$ & ab $34.44 \pm 0.87^{\mathrm{a}}$ & $1.92 \pm 0.96^{\mathrm{ab}}$ & $64.20 \pm 0.98^{\mathrm{a}}$ \\
\hline South Sulawesi & $0.03 \pm 0.05^{\mathrm{a}}$ & $0.15 \pm 0.17^{\mathrm{a}}$ & $0.63 \pm 0.66^{a}$ & $29.20 \pm 0.57$ & a $32.14 \pm 0.46^{b}$ & $1.80 \pm 0.23^{a b}$ & $63.95 \pm 0.75^{a}$ \\
\hline Southeast Sulawesi & $0.10 \pm 0.16^{\mathrm{a}}$ & $0.25 \pm 0.20^{\mathrm{a}}$ & $0.40 \pm 0.32^{a}$ & $26.37 \pm 1.86$ & b $34.35 \pm 1.18^{a b}$ & ND & $61.47 \pm 2.89^{a}$ \\
\hline West Papua & ND & $0.02 \pm 0.01^{\mathrm{a}}$ & $0.19 \pm 0.01^{a}$ & $25.88 \pm 1.64$ & b $37.29 \pm 2.58^{\text {a }}$ & $0.92 \pm 1.01^{b c}$ & $64.31 \pm 0.04^{\mathrm{a}}$ \\
\hline
\end{tabular}


essential fatty acid in cocoa butter acylglycerol shows in range $26.28-29.20 \%$ and 32,14$37.29 \%$, with the highest content C18:0 is in West Papua belong to the high temperature and low rainfall. This effect of high growing temperature and drought in C18:0 also had been evaluated in the soybean by Cheesbrough (1989) to prove its concern in reducing the performance of specific enzyme for saturation.

\section{Unsaturated Fatty Aid Profiles}

Unsaturated fatty acid profiles in growing areas as shown in Table 4 express significant difference only in linolenic acid (C18:3) otherwise its oleic acid (C18:1) which determine cocoa butter characteristic. Tabel 5 shows the correlation of climate condition including rainfall, temperature and humidity to palmitic acid (C16:0) is more obvious than oleic acid (C18:1) which content 32,14$37,29 \%$. Temperature of growing area have correlation value 0.452 in palmitic acid in $\mathrm{p}$ value $<0.05$. These result confirm the effect of temperature rises the palmitic acid content inside Indonesian cocoa butter. Palmitic acid content of these cocoa butter is rather high comply to the commercial cocoa butter ranged 24.4-33.7\% (Liu et al., 2007), but this oleic acid is higher than Malaysian cocoa butter which stated containing oleic acid 26.36-30.49\% (Asep et al., 2008).

\section{Melting Profiles}

Sensory qualification of acceptable cocoa butter for customer preference is already melt in the mouth temperature around 32$34^{\circ} \mathrm{C}$ (Norton et al., 2009). DSC is the most widely used thermal analysis applied to oil and fat studies. Parameters obtained from endothermic thermograms are presented in the Table 6, T.onset ranged from 31.24$33.88^{\circ} \mathrm{C}$, T.peak ranged $36.65-39.20^{\circ} \mathrm{C}$ and T.endset ranged $43.28-45.87^{\circ} \mathrm{C}$. T.onset describe the melting behaviour for complete melting while Central Sulawesi obtain the

Tabel 4. Unsaturated fatty acid composition

\begin{tabular}{|c|c|c|c|c|c|c|c|}
\hline \multirow{2}{*}{ Samples } & \multicolumn{4}{|c|}{ Unsaturated fatty acid (\%) } & \multirow{2}{*}{ ÓUFA, \% } & \multirow{2}{*}{ ÓMUFA, \% } & \multirow{2}{*}{ ÓPUFA, \% } \\
\hline & C16:1 & C18:1 & C18:2 & C18:3 & & & \\
\hline West Sumatera & $0.42 \pm 0.03^{\mathrm{a}}$ & $32.21 \pm 0.68^{\mathrm{a}}$ & $1.85 \pm 0.08^{\mathrm{a}}$ & $0.09 \pm 0.08^{b}$ & $34.58 \pm 0.70^{\mathrm{a}}$ & $32.64 \pm 0.70^{\mathrm{a}}$ & $1.94 \pm 0.00^{\mathrm{a}}$ \\
\hline Lampung & $0.70 \pm 0.36^{\mathrm{a}}$ & $33.05 \pm 0.39^{\mathrm{a}}$ & $1.27 \pm 1.04^{\mathrm{a}}$ & $0.20 \pm 0.04^{\mathrm{ab}}$ & $35.22 \pm 0.69^{a}$ & $33.76 \pm 0.42^{\mathrm{a}}$ & $1.46 \pm 1.05^{\mathrm{a}}$ \\
\hline East Java & $1.87 \pm 2.43^{\mathrm{a}}$ & $32.62 \pm 1.09^{\mathrm{a}}$ & $1.70 \pm 1.13^{\mathrm{a}}$ & $0.24 \pm 0.10^{\text {a }}$ & $36.42 \pm 2.00^{\mathrm{a}}$ & $34.48 \pm 1.41^{\mathrm{a}}$ & $1.94 \pm 1.17^{\mathrm{a}}$ \\
\hline West Sulawesi & $0.42 \pm 0.33^{a}$ & $33.14 \pm 0.55^{\mathrm{a}}$ & $1.74 \pm 0.09^{\mathrm{a}}$ & $0.22 \pm 0.06^{\mathrm{a}}$ & $35.52 \pm 0.76^{\mathrm{a}}$ & $33.56 \pm 0.83^{\mathrm{a}}$ & $1.97 \pm 0.08^{\mathrm{a}}$ \\
\hline Central Sulawesi & $0.46 \pm 0.21^{\mathrm{a}}$ & $32.87 \pm 0.60^{\mathrm{a}}$ & $2.26 \pm 0.33^{\mathrm{a}}$ & $0.20 \pm 0.03$ ab & $35.80 \pm 0.98^{a}$ & $33.34 \pm 0.64^{\mathrm{a}}$ & $2.46 \pm 0.35$ a \\
\hline South Sulawesi & $0.75 \pm 0.38^{\mathrm{a}}$ & $33.25 \pm 0.75^{a}$ & $1.80 \pm 0.29^{a}$ & $0.25 \pm 0.02^{a}$ & $36.05 \pm 0.75^{a}$ & $34.00 \pm 0.55^{\mathrm{a}}$ & $2.04 \pm 0.27^{\mathrm{a}}$ \\
\hline Southeast Sulawesi & $0.90 \pm 0.76^{\mathrm{a}}$ & $32.98 \pm 0.39^{a}$ & $2.30 \pm 0.21^{\mathrm{a}}$ & $0.16 \pm 0.06^{a b}$ & $36.34 \pm 0.94^{\mathrm{a}}$ & $33.88 \pm 1.09^{\mathrm{a}}$ & $2.46 \pm 0.27^{\mathrm{a}}$ \\
\hline West Papua & $0.39 \pm 0.03^{a}$ & $32.77 \pm 0.26^{\mathrm{a}}$ & $2.33 \pm 0.24^{\mathrm{a}}$ & $0.20 \pm 0.01^{a b}$ & $35.69 \pm 0.04^{\mathrm{a}}$ & $33.16 \pm 0.29^{\mathrm{a}}$ & $2.53 \pm 0.25^{\mathrm{a}}$ \\
\hline
\end{tabular}

Note: Mean values assigned with a common letter within the same column are not significantly different according to Duncan's multiple range test at the $5 \%$ level.

Table 5. Pearson correlation of fatty acid and climate condition (rainfall, temperature, and humidity)

\begin{tabular}{lcccrrr}
\hline \multirow{2}{*}{ Fatty Acid } & \multicolumn{2}{c}{ Rainfall } & \multicolumn{2}{c}{ Temperature } & \multicolumn{2}{c}{ Humidity } \\
\cline { 2 - 7 } & Pearson correlation & Sig. & Pearson correlation & Sig. & Pearson correlation & Sig. \\
\hline C10:0 & -0.191 & 0.395 & -0.008 & 0.97 & 0.06 & 0.791 \\
C12:0 & -0.083 & 0.712 & -0.012 & 0.956 & -0.164 & 0.465 \\
C14:0 & 0.010 & 0.965 & 0.105 & 0.643 & -0.088 & 0.696 \\
C16:0 & 0.105 & 0.643 & $0.452^{*}$ & 0.034 & 0.017 & 0.939 \\
C16:1 & -0.315 & 0.153 & $-0.450^{*}$ & 0.036 & 0.104 & 0.647 \\
C18:0 & 0.042 & 0.854 & -0.23 & 0.303 & -0.191 & 0.395 \\
C18: & -0.093 & 0.680 & 0.31 & 0.161 & 0.057 & 0.802 \\
C18:2 & 0.070 & 0.756 & -0.236 & 0.29 & 0.279 & 0.208 \\
C18:3 & -0.070 & 0.756 & 0.268 & 0.228 & -0.248 & 0.266 \\
C20:0 & 0.321 & 0.145 & 0.02 & 0.929 & -0.101 & 0.654 \\
\hline Note: & Correlationyyyyyyyyyyy is significant at the 0.05 level. & & & &
\end{tabular}


Tabel 6. Cocoa butter melting profile

\begin{tabular}{|c|c|c|c|c|}
\hline Samples & $\mathrm{T}$ onset, ${ }^{\circ} \mathrm{C}$ & $\mathrm{T}$ peak, ${ }^{\circ} \mathrm{C}$ & $\mathrm{T}$ endset, ${ }^{\circ} \mathrm{C}$ & ÄH, J/g \\
\hline West Sumatera & $32.81 \pm 0.12 \mathrm{ab}$ & $37.95 \pm 0.96^{\mathrm{a}}$ & $44.11 \pm 1.82 \mathrm{ab}$ & $88.58 \pm 2.27$ ab \\
\hline Lampung & $32.11 \pm 0.78^{a b}$ & $38.72 \pm 0.08^{\mathrm{a}}$ & $45.37 \pm 0.35$ ab & $83.98 \pm 0.23^{a b}$ \\
\hline East Java & $33.17 \pm 1.29 \mathrm{ab}$ & $38.08 \pm 0.82 \mathrm{ab}$ & $44.29 \pm 0.64$ ab & $69.19 \pm 4.92 \mathrm{ab}$ \\
\hline West Sulawesi & $32.81 \pm 0.97 \mathrm{ab}$ & $38.65 \pm 0.19^{a b}$ & $45.87 \pm 0.66^{\mathrm{a}}$ & $86.97 \pm 2.36^{\mathrm{a}}$ \\
\hline Central Sulawesi & $33.88 \pm 0.27^{\mathrm{a}}$ & $39.20 \pm 0.68^{\mathrm{a}}$ & $45.34 \pm 0.44 \mathrm{ab}$ & $66.47 \pm 8.53^{b}$ \\
\hline South Sulawesi & $32.13 \pm 0.77 \mathrm{ab}$ & $38.74 \pm 1.38^{\mathrm{a}}$ & $44.98 \pm 1.93 \mathrm{ab}$ & $80.38 \pm 5.36$ ab \\
\hline Southeast Sulawesi & $31.24 \pm 1.73^{b}$ & $36.65 \pm 0,71^{\mathrm{b}}$ & $43.28 \pm 0.97^{b}$ & $73.56 \pm 7.01$ ab \\
\hline West Papua & $32.95 \pm 0.06^{\mathrm{ab}}$ & $38.45 \pm 1.48^{\mathrm{a}}$ & $44.54 \pm 1.85$ ab & $81.54 \pm 9.31$ ab \\
\hline
\end{tabular}

highest melting point $39.20^{\circ} \mathrm{C}$ and Southeast Sulawesi in the lowest poin. In accordance to Table 1, Central Sulawesi and Southeast Sulawesi have similarities in growing temperature but Central Sulawesi have more intensity in rainfall that would be the reason in the total amount of saturated fatty acid (SFA) and the lowest Southeast Sulawesi as shown in Table 3. Indonesian cocoa butter melt in $36.65-39.20^{\circ} \mathrm{C}$ is much higher compare to melting point of Brazilian cocoa butter in $21.07^{\circ} \mathrm{C}$ (Vieira et al, 2015). This result prove the classification of Indonesian butter as one of hard cocoa butter (Beckett, 2009).

\section{Solid Fat Content Profiles}

The SFC of cocoa butter and its blends is an important quality parameter in the technological process of chocolate manufacture. Cocoa butter SFC values calculated at temperatures in the range of $27-33^{\circ} \mathrm{C}\left(\mathrm{T}_{1}\right)$ indicate intensive melting of cocoa butter occurs, and value at temperatures above $35^{\circ} \mathrm{C}\left(\mathrm{T}_{2}\right)$ signals the presence of a fat fraction which causes a waxy taste (Torbica et al., 2005). Table 7 shows SFC value in $\mathrm{T}_{1}$ ranged $7.288-16.82 \%$ and $\mathrm{T}_{2}$ ranged $0.02-0.29 \%$. $\mathrm{T}_{1}$ for SSL is $7.28 \%$ as the lowest and West Papua as the highest SFC in value $18.82 \%$, although SSL and West Papua have no difference in enthalpy and melting point as shown in Table 6, but South Sulawesi and West Papua declare gap value for stearic acid content and total unsaturated fatty acid at Table 3. Average SFC value of Indonesian cocoa butter is $12.46 \%$ for $T_{1}$ and approximately higher than Brazilian cocoa butter but lower than Ghanaian cocoa butter. Bazilian cocoa butter have SFC $6.6 \%$ in $32.5^{\circ} \mathrm{C}$ lower than Ghanaian $13.3 \%$, but in setting temperature $\mathrm{T}_{2}$, both Brazilian and Ghanaian cocoa butter are completely melted (Beckett, 2009; Vieira et al., 2015).

Tabel 7. Solid fat content value

\begin{tabular}{lrc}
\hline Samples & $\mathrm{T}_{1}=33^{\circ} \mathrm{C}(\%)$ & $\mathrm{T}_{2}=38^{\circ} \mathrm{C}(\%)$ \\
\hline West Sumatera & $13.59 \pm 3.35^{\mathrm{ab}}$ & $0.11 \pm 0.02^{\mathrm{a}}$ \\
Lampung & $13.44 \pm 0.62^{\mathrm{ab}}$ & $0.02 \pm 0.07^{\mathrm{a}}$ \\
East Java & $9.05 \pm 0.41^{\mathrm{ab}}$ & $0.29 \pm 0.09^{\mathrm{a}}$ \\
West Sulawesi & $13.50 \pm 0.79^{\mathrm{ab}}$ & $0.07 \pm 0.01^{\mathrm{a}}$ \\
Central Sulawesi & $11.96 \pm 0.52^{\mathrm{ab}}$ & $0.10 \pm 0.27^{\mathrm{a}}$ \\
South Sulawesi & $7.28 \pm 1.98^{\mathrm{b}}$ & $0.09 \pm 0.04^{\mathrm{a}}$ \\
Southeast Sulawesi & $14.04 \pm 2.21^{\mathrm{ab}}$ & $0.28 \pm 0.06^{\mathrm{a}}$ \\
West Papua & $16.82 \pm 3.38^{\mathrm{a}}$ & $0.14 \pm 0.37^{\mathrm{a}}$ \\
\hline Note: Mean values assigned with a common letter within \\
\multicolumn{3}{c}{ the same column are not significantly different } \\
\multicolumn{2}{c}{ according to Duncan's multiple range test at the }
\end{tabular}

\section{CONCLUSIONS}

Characteristic of Indonesian cocoa butter described in fatty acid composition consist of palmitic acid 26.28-29.20\%, stearic acid $32.14-37.29 \%$ and oleic acid 32.14$37.29 \%$. Geographic region of growing area shows similar climate condition but temperature of growing specifically influence the palmitic acid composition changes compare to rainfall and humidity. Physical properties of cocoa butter describe in melting point of $36.65-39.20^{\circ} \mathrm{C}$ also solid fat content ranged 
$7.288-16.82 \%$ in $33^{\circ} \mathrm{C}$ and ranged $0.02-$ $0.29 \%$ in $38^{\circ} \mathrm{C}$. Indonesian cocoa butter confirmed to be classified as hard cocoa butter source where in temperature $38^{\circ} \mathrm{C}$ still have solid component but Ghanaian and Brazilian cocoa butter completely melted.

\section{REFERENCES}

Afoakwa, E.O. (2014). Cocoa Production and Processing Technology. CRC Press: Florida.

Afoakwa, E.O.;E. Ofosu-Ansah; J.F. Takrama; A.S. Budu \& H. Mensah-Brown (2014). Changes in chemical quality of cocoa butter during roasting of pulp pre-conditioned and fermented cocoa (Theobroma cacao) beans. International Food Research Journal, 21, 2221-2227.

Amissah, L.; G.M.J. Mohren; F. Bongers; W.D. Hawthorne \& L. Poorter (2014) Rainfall and temperature affect tree species distribution in Ghana. Journal of Tropical Ecology, 30, 435-446.

Asep, E.K.; S. Jinap; T.J. Tan; A.R. Russly; S. Harcharan \& S.A.H. Nazimah (2008). The effects of particle size, fermentation and roasting of cocoa nibs on supercritical fluid extraction of cocoa butter. Journal of Food Engineering, $85,450-458$.

Beckett, S.T. (2009). Industrial Chocolate Manufacture and Use, $4^{\text {th }}$ Edition. Blackwell Publishing Ltd: United Kingdom.

Cheesbrough, T.M. (1989). Changes in the enzymes for fatty acid synthesis and desaturation during acclimation of developing soybean seeds to altered growth temperature. Plant Physiology, 90, 760-764.

Firmanto, H.; L. Aklimawati \& B.S. Abdurrizal (2016). Performance of Roasted Cocoa Bean Winnower for Smallholder Chocolate Producers. Pelita Perkebunan, 32, 120-129.

Gu, F.; L. Ta; H. Wu; Y. Fang; F. Xu; Z. Chu \& W. Qinghuang (2013). Comparison of cocoa beans from China, Indonesia and Papua New Guinea. Journal of Foods, 2, 183-197.

Hartman, L. \& R.C. Lago (1973) Rapid preparation of fatty acid esters from lipids. Lab Pract, 22, 475-476.

ICCO (2018). ICCO Quarterly Bulletin of Cocoa Statistics Vol. XLIV, No. 3.

Jahurul, M.H.A.; I.S.M. Zaidul; N.A.N. Norulaini; F. Sahena; M.Z. Abedin; A. Mohamed \& A.K.M. Omar (2014). Hard cocoa butter replacers from mango seed fat and palm stearin. Journal of Food Chemistry, 154, 323-329.

Lehrian, D.W. \& P.G. Keeney (1980) Triglyceride characteristics of cocoa butter from cacao fruit maturated in a microclimate of elevated temperature. Journal of American Oil Chemical Society, 57, 66-69.

Liu, K.; H. Chang \& L. Kuan-Miao (2007). Enzymatic sythesis of cocoa butter analog through interesterification of lard and stearin in supercritical $\mathrm{CO} 2$ by lipase. Journal of Food Chemistry, 100, 1303-1311.

McMahon, P.; H. Bin Purung; S. Lambert; S. Mulia; Nurlaila.; A.W. Susilo; E. Sulistyowati; S. Sukamto; M. Israel; Saftar; Ashar; A. Amir; A. Purwantara; A. Iswanto; D. Guest \& P. Keane (2015). Testing local cocoa selection in three provinces in sulawesi: productivity and resistance to cocoa pod borer and phytopthora pod rot. Crop Production, 70, 28-39.

Mulato, S.; S. Widyotomo \& H.N. Aini (2004). Performance of cylindrically rotary type of cocoa grinder. Pelita Perkebunan, $22,37-54$.

Norton, J.E.; P.J. Fryer \& P.W. Cox (2009). Development and characterisation of tempered cocoa butter emulsions containing up to $60 \%$ water. Journal of Food Engineering, 95, 172-178.

Saldaña, M.D.A.; R.S. Mohamed \& P. Mazzafera (2002). Extraction of cocoa butter from Brazilian cocoa beans using supercritical 
$\mathrm{CO} 2$ and ethane. Fluid Phase Equilibria 194-197: 886.

Spangenberg, J.E. \& F. Dionisi (2001). Characterization of cocoa butter and cocoa butter equivalents by bulk and molecular carbon isotope analyses: implications for vegetable fat quantification in chocolate. Journal of Agricultural and Food Chemistry, 49, 4271-4277.

Torbica, A.; O. Jovanovic \& B. Pajin (2005). The advantages of solid fat content determination in cocoa butter and cocoa butter equivalents by the karlshamns method. european Food Research and Technology, 222, 385-391.

Upchurch, R.G. (2008). Fatty acid unsaturation, mobilization and regulation in the response of plant to stress. Biotecnology Letter, 30, 967-977.
Venter, M.J.; N. Schouten; R. Hink; N.J.M. Kuipers $\&$ A.B. de Haanb (2007). Expression of cocoa butter from cocoa nibs. Journal of Separation and Purification Technology, 55, 256-264.

Vieira, L.; PEfraim.; D. Van de Walle; N. De Clercq $\&$ K. Dewettinck (2015). Influence of Brazilian Geographic Region and Organic Agriculture on The Composition and Crystallization Properties of Cocoa Butter. Journal of American Chemical Society, 92, 1579-1592.

Żyżelewicz, D.; W. Krysiak; G. Budryn; J. Oracz \& E. Nebesny (2014). Tocopherols in cocoa butter obtained from cocoa bean roasted in different forms and under various process parameters. Journal of Food Research International, 63, 390-399.

$* * 0 * *$ 